\title{
VERBALS BULLYING RELATED TO SELF-ESTEEM ON ADOLESCENTS
}

\author{
Jek Amidos Pardede ${ }^{1}$, Akhyarul Huda ${ }^{1}$, Masri Saragih ${ }^{1}$, Marthalena Simamora ${ }^{1}$ \\ ${ }^{1}$ Program Studi Keperawatan Universitas Sari Mutiara Indonesia \\ Corresponding author: jekpardedemi@rocketmail.com
}

\begin{abstract}
Background: bullying is a problem of global concern that can have serious / negative effects on the mental health and well-being of adolescents. Bullying that often occurs is verbal bullying which can affect self-esteem.

Purpose: to determine the relationship between bullying and self-esteem on adolescents.

Methods: the design of this research is descriptive correlation with cross sectional approach. The population of the study were 83 students of class X Senior High School who experienced bullying and the sample of this study was the entire population with the sampling technique using total sampling. The data collection tool used a questionnaire that had been tested for validity and reliability, the statistical test used was the chi-square test with $p<0.05$.

Results: the study showed that the majority of verbal bullying was moderate as much as $43.4 \%$ and the majority of the majority were low self-esteem as much as $46.6 \%$ with $p=$ 0.004 .
\end{abstract}

Conclusion: there is a significant relationship between verbal bullying and self-esteem.

\section{Keywords:}

Adolescents; self-esteem; verbal bullying.

\section{LATAR BELAKANG}

Bullying merupakan perilaku agresi yang disengaja dan berlangsung secara terusmenerus yang ditujukan pada individu yang sudah menjadi incaran atau korban. Bullying juga dikatakan perilaku yang tidak diinginkan/ perilaku agresif pada anak usia sekolah yang terjadi karena ketidakseimbangan kekuatan (Herman, Nurshal \& Oktarina, 2018). Bullying terjadi pada semua tingkat usia, tetapi mulai meningkat pada akhir sekolah dasar, puncak di sekolah menengah, dan umumnya menurun di sekolah tinggi (Liu \& Graves, 2011). Perilaku bullying juga dipengaruhi oleh tipe kepribadian individu, umumnya cenderung terjadi pada pada remaja dengan tipe kepribadian extrovert dan orang yang extrovert sangat berbahaya bagi individu, apabila ikatan dengan dunia luar terlampau kuat, sehingga ia tenggelam dalam dunia objektif, kehilangan dirinya, atau asing terhadap dunia subjektifnya sendiri (Zaman, 2009 dalam, Putri, Nauli \& Novayelinda, 2015). 
Prevalensi bullying di Amerika Serikat adalah 20,8\% pada bullying fisik, 53,6\% verbal,51,4\% sosial, dan 13,6\% elektronik (Wang et al, 2009 dalam Marela, Wahab \& Marchira, 2017). Komisi Perlindungan Anak Indonesia (KPAI) tahun 2014 mencatat bahwa dari total pengaduan bullying, yang terjadi di bidang pendidikan sebanyak 1.480 kasus. Bullying yang disebut KPAI sebagai bentuk kekerasandi sekolah, mengalahkan tawuran pelajar, diskriminasi pendidikan ataupun aduan pungutan liar (Republika, 2014). Fenomena perilaku bullying merupakan bagian dari kenakalan remaja dan diketahui paling sering terjadi pada masa-masa remaja, dikarenakan pada masa ini remaja memiliki egosentrisme yang tinggi (Putri, Nauli \& Novayelinda, 2015)

Menurut Wiyani (2012) tindakan bullying cenderung disepelekan atau kurang diperhatikan dalam kehidupan sehari-hari. Masih banyak yang menganggap bahwa bullying tidak berbahaya, padahal sebenarnya bullying dapat memberikan dampak negatif bagi korbannya yaitu ketika mengalami bullying korban akan merasakan banyak emosi negatif dimana korban tidak berdaya dalam menghadapi emosi. Dalam jangka panjang, maka emosi-emosi ini dapat berujung pada munculnya perasaan rendah diri, apabila hal ini dibiar merasa dirinya tidak berharga sehingga dapat berujung pada terjadinya bunuh diri. Sehingga untuk mencegah terjadinya bunuh diri perlulah peningkatan harga diri karena harga diri adalah penilaian individu terhadap kehormatan diri, melalui sikap terhadap dirinya sendiri yang bersifat implisit dan tidak diucapkan secara verbal serta menggambarkan bagaimana individu menilai dirinya sendiri sebagai individu yang memiliki kemampuan, berharga dan berkompeten (Aini, 2018).

Hasil survey awal yang dilakukann menunjukkan $70 \%$ dari 10 siswa kelas $\mathrm{X}$ yang diwawancarai pernah mengalami perilaku bullying baik itu berupa julukan nama, cemoohan, ejekan, dikucilkan. Jenis bullying yang sering terjadi disekolah, 70\% siswa mengatakan bullying menjuluki, 10\% siswa mengatakan bullying menebar gossip selebihnya $20 \%$ siswa mengatakan aksi senioritas terhadap junior. Sesuai dengan uraian di atas, Peneliti tertarik untuk meneliti hubungan bullying verbal dengan harga diri pada remaja di kelas X SMA.

\section{TUJUAN}

Untuk mengetahui hubungan Bullying verbal dengan harga diri Remaja di kelas X SMA

\section{METODE}

Desain penelitian ini adalah deskriptif korelasi dengan pendekatan cross sectional. Populasi penelitian ini adalah siswa/i kelas X SMA Negeri 01 Bendahara Kabupaten Aceh Tamiang yaitu kelas X-1 sebanyak 31 orang, X-2 sebanyak 34 orang, X-3 sebanyak 32 orang dan Kelas X-4 sebanyak 32 orang sehingga total kelas X adalah sebanyak 129 orang. Sampel pada penelitian ini adalah siswa/i kelas $\mathrm{X}$ yang mengalami bullying berjumlah 83 siswa. Data siswa yang mengalami bullying ini didapatkan dari hasil rekapitulasi guru Bimbingan Konseling (BK). Teknik pengambilan sampel pada penelitian ini adalah total sampling yaitu pengambilan sampel secara keseluruhan dari jumlah siswa yang mengalami bullying. Alat pengumpulan data dengan mengunakan kuesioner yang sudah di uji validitas dan reabilitas. Unutk kuesioner bullying verbal sebanyak 15 pernyataan didapatkan nilai cronbach's alpha yaitu 0.970 dan untuk kuesioner harga diri sebanyak 20 pernyataan didapatkan nilai cronbach's alpha yaitu 
0.911. Analisa bivariat menggunakan uji Chi-Square pada $\alpha<(0,05)$ dengan confidensi interval (CI) $95 \%$.

\section{HASIL}

Hasil penelitian tentang data demografi remaja menunjukkan usia responden mayoritas 16 tahun sebanyak $74.7 \%$ dan jenis kelamin responden mayoritas perempuan sebanyak $65.1 \%$.

Tabel 1. Bullying Verbal Pada Remaja $(\mathrm{n}=83)$

\begin{tabular}{lcc}
\hline Bullying Verbal & $n$ & $\%$ \\
\hline Tinggi & 24 & 28,9 \\
Sedang & 36 & 43,4 \\
Rendah & 23 & 27,7 \\
& & \\
\hline
\end{tabular}

Berdasarkan tabel 1, dapat dilihat bahwa bullying verbal mayoritas sedang sebanyak $43.4 \%$.

Tabel 2. Harga Diri Pada Remaja ( $n=83)$

\begin{tabular}{lll}
\hline Harga Diri & $n$ & $\%$ \\
\hline Tinggi & 19 & 22.9 \\
Sedang & 27 & 32.5 \\
Rendah & 37 & 44.6 \\
\end{tabular}

Berdasarkan tabel 2, dapat dilihat bahwa harga diri remaja mayoritas rendah sebanyak $44.6 \%$.

Tabel 3. Hubungan Bullying Verbal Dengan Harga Diri Pada Remaja ( $\mathrm{n}=83$ )

\begin{tabular}{|c|c|c|c|c|c|c|c|c|c|}
\hline \multirow{3}{*}{$\begin{array}{c}\text { Bullying } \\
\text { Verbal }\end{array}$} & \multicolumn{6}{|c|}{ Harga Diri } & \multicolumn{2}{|c|}{ Jumlah } & \multirow{2}{*}{$\begin{array}{c}P- \\
\text { Value }\end{array}$} \\
\hline & \multicolumn{2}{|c|}{ Tinggi } & \multicolumn{2}{|c|}{ Sedang } & \multicolumn{2}{|c|}{ Rendah } & & & \\
\hline & $\mathrm{n}$ & $\%$ & $\mathrm{n}$ & $\%$ & $\mathrm{n}$ & $\%$ & $\mathrm{n}$ & $\%$ & \\
\hline Tinggi & 2 & 2.4 & 6 & 7.2 & 16 & 19.3 & 24 & 28.9 & \\
\hline Sedang & 6 & 7.2 & 15 & 18.1 & 15 & 18.1 & 36 & 43.4 & 0,004 \\
\hline Rendah & 11 & 13.3 & 6 & 7.2 & 6 & 7.2 & 23 & 27.7 & \\
\hline Jumlah & 19 & 22.9 & 27 & 32.5 & 37 & 44.6 & 83 & 100 & \\
\hline
\end{tabular}


Berdasarkan tabel 3, dapat dilihat bahwa $28.9 \%$ responden mengatakan bullying verbal dalam kategori tinggi dengan dengan harga diri pada remaja rendah $19.3 \%$, sedang $7.2 \%$ dan tinggi $2.4 \%$. Sebagian besar responden yaitu $43.4 \%$ mengatakan bahwa bullying verbal dalam kategori sedang dengan harga diri pada remaja rendah $18.1 \%$, sedang $18.1 \%$ dan tinggi $7.2 \%$. Sedangkan $27.7 \%$ responden mengatakan bahwa bullying verbal dalam kategori rendah dengan harga diri pada rendah $7.2 \%$, sedang $7.2 \%$ dan tinggi $13.3 \%$. Hasil uji Chi-square menunjukkan bahwa ada hubungan antara bullying verbal dengan harga diri pada remaja $(\mathrm{p}=0.004)$.

\section{PEMBAHASAN}

Hasil penelitian didapatkan bahwa bullying verbal mayoritas sedang sebanyak $43.4 \%$. Hal ini terjadi diakibatkan atas kurangnya perhatian dan sikap proaktif dalam menanggulangi perilaku bullying terutama di sekolah. Hasil survei dari Plan Indonesia tentang perilaku kekerasan di sekolah mengungkapkan 67,9\% responden menganggap telah terjadi kekerasan disekolah, berupa kekerasan verbal (Rogamelia, 2014). Hasil penelitian yang dilakukan Marela, Wahab \& Marchira (2017) bahwa remaja lebih sering mengalami bullying secara verbal dibandingkan dengan jenis bullying lainnya yaitu 47\%. Kejadian bullying verbal dapat terjadi pada sekolah yang memiliki tingkat pengawasan dan bimbingan etika yang rendah, kedisiplinan yang rendah, peraturan sekolah yang lemah.

Permasalahan yang sering dihadapi para remaja (siswa) berhubungan dengan penolakan teman sebaya yaitu munculnya bullying yang merupakan bentuk khusus agresi dikalangan teman sebaya yang dikenal sebagai masalah sosial terutama ditemukan dikalangan anak-anak sekolah (Krahe, 2005 dalam Saifullah, 2015). Menurut Thompson (2019) bullying adalah tindakan bermusuhan yang dilakukan secara sadar dan disengaja yang bertujuan untuk menyakiti, seperti menakuti melalui ancaman agresi dan menimbulkan teror. Termasuk juga tindakan yang direncakan maupun yang spontan, bersifat nyata atau hampir tidak kentara, di hadapan seseorang atau di belakang seseorang, mudah untuk diidentifikasi atau terselubung dibalik persahabatan, dilakukan oleh seorang anak atau kelompok anak. Perilaku bullying verbal adalah suatu tindakan negatif berulang yang dilakukan secara sadar dan disengaja yang bermaksud untuk menyebabkan ketidaksenangan atau menyakitkan orang lain.

Hasil penelitian ini didapatkan bahwa harga diri remaja mayoritas rendah sebanyak 44.6\%. Hal ini disebabkan karena identitas berkelompok yang dimilki, juga mempengaruhi harga diri remaja. Menurut Hapsari \& Retnaningsih (2011) harga diri dan disiplin sekolah dapat digunakan sebagai prediktor untuk memprediksikan perilaku bullying seseorang yang mengembangkan penilaian positif tentang dirinya berarti memiliki harga diri yang baik, tetapi jika seseorang mengembangkan penilaian negatif tentang dirinya sendiri berarti memiliki harga diri yang buruk.

Faktor-faktor yang mempengaruhi harga diri pada siswa yang menjadi korban bullying antara lain adalah: penerimaan diri, dukungan sosial, keluarga, kesuksesan, status dan prestasi yang pernah diraih seseorang dan agama (Mardina \& Lestari, 2018). Menurut Sandri (2015) Dukungan sosial merupakan aspek penting bagi remaja untuk bisa beradaptasi dengan baik, terutama dukungan dari teman sebaya. Selain kelekatan dengan teman sebaya, harga diri memberikan pengaruh yang signifikan terhadap 
perilaku bullying remaja. Sehingga dapat dikatakan bahwa salah satu factor yang berperan dalam pengembangan perilaku bullying adalah harga diri. Harga diri yang tinggi dikaitkan dengan kecemasan yang rendah, efektif dalam kelompok dan penerimaan orang lain terhadap dirinya (Pardede, Hutajulu \& Pasaribu, 2020). Harga diri seseorang dapat dipengaruhi dari dalam diri maupun dari luar. Penilaian diri seseorang akan dirinya dipengaruhi oleh lingkungan dimana individu berada, di rumah maupun di sekolah dan bagaimana seseorang diperlakukan. Apabila seorang remaja disekolah mendapatkan tindakan yang menyebabkan seseorang tersakiti maka akan mengakibatkan harga diri remaja menjadi rendah.

Hasil penelitian ini didapatkan bahwa ada hubungan yang signifikan antara bullying verbal dengan harga diri pada remaja. Hal ini dibuktikan dengan hasil kuisioner sebagian besar responden yaitu 37.3\% mengatakan sering dihina dengan kata-kata yang kasar dengan harga diri remaja sebagian besaryaitu $22.9 \%$ dalam kategori rendah. Hal ini disebabkan karena dihina dengan kata-kata yang kasar remaja beranggapan hal itu merupakan hal yang wajar dilakukan untuk teman sebaya, akan tetapi harga diri remaja yang menjadi korban sebagian besar dalam kategori rendah, karena dengan menghina dengan kata kata kasar menyakitkan hati dan memberikan efek psikologis yang negatif yaitu harga diri rendah. Hal ini juga dibuktikan dengan kuisioner berikutnya yaitu dipanggil oleh teman dengan sebutan nama hewan sebagian besar responden yaitu 43.3\% mengatakan bullying sering dialamidengan harga diri sebagian besar yaitu $21.6 \%$ dalam ketegori rendah. Bullying verbal ini terjadi karena dengan memberikan nama julukan, memanggil dengan panggilan orang tua, mengejek dan menghina dengan kata kata yang kasar dapat mengakibatkan dampak psikologis (harga diri) yang rendah pada korbannya.

Dikalangan remaja, bullying verbal merupakan suatu hal yang wajar bagi remaja usia sekolah dengan memberikan nama julukan kepada temannya yang dianggap lucu hanya untuk iseng. Bullying yang dilakukan oleh remaja lebih banyak dilakukan secara verbal untuk menjalin hubungan dengan orang lain, seperti menggosipkan teman sekelas, berusaha membalas dendam dengan cara menghina, mengejek, dan dipermalukan. Walaupun verbal bullying tidak menyebabkan kerusakan fisik, tapi penggencetan seperti ini dapat memberikan dampak buruk pada sisi psikologis korban (Suciart 21 Sumartini, 2019).

Tingginya kecenderungan bullying verbal disebabkan karena secara umum remaja (siswa) memandang bullying verbal merupakan hal yang biasa dan wajar bahkan tidak memiliki efek, dampak, atau konsekuensi yang serius dibandingkan dengan jenis bullying lainnya. Bullying verbal biasanya dilakukan oleh remaja (siswa) pada teman yang susah bergaul, teman yang memiliki kelemahan fisik, perilaku ataupun penampilannya yang berbeda. Sehingga jenis bullying ini sering dilakukan oleh remaja (siswa) dikarenakan bullying ini mudah dilakukan, dapat dilakukan kapan dan dimanapun, tidak meninggalkan bekas pada fisik korban, dan apabila ketahuan oleh guru pada saat sedang membully tidak mudah ketahuan karena tidak meninggalkan bukti. Akan tetapi bullying verbal ini memberikan dampak negatif pada korbannya bahkan efek melekat seumur hidup karna sakit hati yang mendalam. 
Jendela Nursing Journal, 5(1), 2021,

\section{SIMPULAN}

Hasil penelitian dapat disimpulkan bahwa bullying verbal mayoritas sedang, harga diri mayoritas rendah dan ada hubungan yang signifikan antara bullying verbal dengan harga diri pada remaja. Guru BK seharusnya memberikan evaluasi terkait kejadian bullying verbal pada anaka dan coba memberikan umpanbalik untuk membantu anak keluar dari masalah tersebut.

\section{REFERENSI}

Aini, D. F. N. (2018). Self Esteem Pada Anak Usia Sekolah Dasar Untuk Pencegahan Kasus Bullying. Jurnal Pemikiran Dan Pengembangan Sekolah Dasar (Jp2sd), 6(1), 36-46. https://doi.org/10.22219/jp2sd.v6i1.5901

Hapsari, R. M., \& Retnaningsih, R. (2011). Perilaku asertif dan harga diri pada karyawan. Jurnal psikologi, 1(1). https://ejournal.gunadarma.ac.id/index.php/psiko/article/view/276

Herman, H., Nurshal, D., \& Oktarina, E. (2018). Hubungan karakteristik remaja dengan perilaku bullying pada siswa SMP Di Kota Padang. Jurnal Keperawatan Soedirman, 12(1), 1-11. http://dx.doi.org/10.20884/1.jks.2017.12.1.677

Liu, J., \& Graves, N. (2011). Childhood bullying: A review of constructs, concepts, and nursing implications. Public health nursing, 28(6), 556-568. https://doi.org/10.1111/j.1525-1446.2011.00972.x

Mardina, M., \& Lestari, R. (2018). Harga diri siswa smp yang menjadi korban bullying di Surakarta. Sikripsi, Universitas Muhammadiyah Surakarta. http://eprints.ums.ac.id/65410/

Marela, G., Wahab, A., \& Marchira, C. R. (2017). Bullying verbal menyebabkan depresi pada remaja SMA di Kota Yogyakarta. Berita Kedokteran Masyarakat, 33(1), 43-48. https://doi.org/10.22146/bkm.8183

Pardede, J. A., Hutajulu, J., \& Pasaribu, P. E. (2020). Harga Diri dengan Depresi Pasien Hiv/aids. Jurnal Media Keperawatan: Politeknik Kesehatan Makassar, 11(01). https://doi.org/10.32382/jmk.v11i1.1538

Putri, H. N., Nauli, F. A. \& Novayelinda, R. (2015). Faktor-faktor yang berhubungan dengan perilaku bullying pada remaja. Jurnal Onlien Mahasiswa, 2(2), 11491159. https://jom.unri.ac.id/index.php/JOMPSIK/article/view/8279

Republika Online. (2014). Aduan Bullying Tertinggi. http://www.republi..... co.id/berita/koran/halaman-1/14/10/15/ndh4sp-aduan-bullying tertinggi

Rogamelia, R. (2014) Efektivitas Penggunaan Konseling Model Sequentially Planned Integrative Counseling For Children (Spicc) Untuk Meningkatkan Perilaku 
Jendela Nursing Journal, 5(1), 2021,

Asertif Korban Bullying. S2 Thesis, Universitas Pendidikan Indonesia. http://repository.upi.edu/6193/

Saifullah, F. (2015). Hubungan Antara Konsep Diri Dengan Bullying. Psikoborneo: Jurnal Ilmiah Psikologi, 3(3), 289-301.

Sandri, R. (2015). Perilaku bullying pada remaja panti asuhan ditinjau dari kelekatan dengan teman sebaya dan harga diri. Jurnal Psikologi Tabularasa, 10(1). 43.22 http://jurnal.unmer.ac.id/index.php/jpt/article/view/242

Suciartini, N. N. A., \& Sumartini, N. L. P. U. (2019). Verbal Bullying dalam Media Sosial. Jurnal Pendidikan Bahasa Indonesia, 6(2), 152-171. http://dx.doi.org/10.30659/j.6.2.152-171

Thompson, E. M. (2019). Understanding Bullying and the Necessity for Prevention and Intervention in Schools. Thesis. https://digitalcommons.liberty.edu/honors/869/

Wiyani, N. A. (2012). Save our children from school bullying. Jogjakarta: Ar-Ruzz Media. 